\title{
SLURRY TREATMENT WITH FOOD INDUSTRY WASTES FOR REDUCING METHANE, NITROUS OX- IDE AND AMMONIA EMISSIONS
}

\author{
M. Samer*, E. Mostafa**, A. M. Hassan**
}

ABSTRACT

Livestock manure is the main source of ammonia $\left(\mathrm{NH}_{3}\right)$ emissions and an important source of greenhouse gases $(\mathrm{GHG})$ especially methane $\left(\mathrm{CH}_{4}\right)$ and nitrous oxide $\left(\mathrm{N}_{2} \mathrm{O}\right)$. Ammonia emissions contribute to eutrophication and acidification of water, soils and ecosystems. The greenhouse gases contribute to the global warming. These gaseous emissions can be reduced by controlling the $\mathrm{pH}$-value of manure. Acidifying the manure can reduce $\mathrm{CH}_{4}, \mathrm{~N}_{2} \mathrm{O}$ and $\mathrm{NH}_{3}$ emissions. Inorganic acids are feasible, but have several disadvantages, e.g. soil contaminants. The use of organic acids is an efficient but expensive method; therefore using the food industry wastes which already contain organic acids is highly feasible. The objective of this research is to investigate the effects food industry wastes as manure additives on the emissions of $\mathrm{CH}_{4}, \mathrm{~N}_{2} \mathrm{O}$ and $\mathrm{NH}_{3}$. Dairy cattle manure was treated with food industry wastes (whey and waste of citrus and orange juices industry) and the gas flux of $\mathrm{CH}_{4}, \mathrm{~N}_{2} \mathrm{O}$ and $\mathrm{NH}_{3}$ were quantified using a specially designed gas detection system which consists of several flasks and a multi-gas monitor. The results showed that the gas fluxes emitted from manure treated with waste of citrus juice industry were 13, 0.219 and $2.523 \mathrm{~g} \mathrm{~m}^{-2}$ day $^{-1}$ for $\mathrm{CH}_{4}, \mathrm{~N}_{2} \mathrm{O}$ and $\mathrm{NH}_{3}$ respectively. The gas fluxes emitted from manure treated with waste of orange juice industry were $13.58,0.223$ and $2.581 \mathrm{~g} \mathrm{~m}^{-2}$ day $^{-1}$ for $\mathrm{CH}_{4}, \mathrm{~N}_{2} \mathrm{O}$ and $\mathrm{NH}_{3}$ respectively. The gas fluxes emitted from manure treated with whey were 17.45, 0.279 and $3.063 \mathrm{~g} \mathrm{~m}^{-2}$ day $^{-1}$ for $\mathrm{CH}_{4}, \mathrm{~N}_{2} \mathrm{O}$ and $\mathrm{NH}_{3}$ respectively. The gas fluxes emitted from the control sample (mixture of manure and water) were 58.21, 0.347 and $18.9 \mathrm{~g} \mathrm{~m}^{-2}$ day $^{-1}$ for $\mathrm{CH}_{4}, \mathrm{~N}_{2} \mathrm{O}$ and $\mathrm{NH}_{3}$ respectively.

\footnotetext{
* Assoc. Prof., Ag. Eng. Dept., Fac. of Agric., Cairo University. ** Assist. Prof., Ag. Eng. Dept., Fac. of Agric., Cairo University.
} 
Consequently, manure treatment with food industry wastes enabled high reduction rates of gaseous emissions from manure.

Keywords: Manure management, slurry treatment, food industry wastes, emissions abatement techniques, emission factors, greenhouse gases, ammonia, methane, nitrous oxide.

\section{INTRODUCTION}

7 he Kyoto Protocol, which is a protocol to the United Nations Framework Convention on Climate Change (UNFCCC), aimed at

1 achieving the stabilization of greenhouse gas concentrations in the atmosphere at a level that would prevent dangerous anthropogenic interference with the climate system. Under this protocol, several countries committed themselves to a reduction of the greenhouse gases. Furthermore, the Gothenburg Protocol is a multi-pollutant protocol designed to reduce acidification, eutrophication and ground-level ozone by setting emissions ceilings for several pollutants, where ammonia is one of them. On the other side, the agriculture (with its two main sectors: plant and animal production) is one of the main sources of greenhouse gases emissions and the main source of ammonia emissions. Thus, reducing greenhouse gases and ammonia emissions from the agricultural sector is crucial.

Enteric fermentation and manure management account for $35 \%$ to $40 \%$ of the total anthropogenic methane $\left(\mathrm{CH}_{4}\right)$ emissions and $80 \%$ of $\mathrm{CH}_{4}$ release from agriculture $(\boldsymbol{F A O}, 2006)$. Livestock activities contribute with $65 \%$ of the global anthropogenic nitrous oxide $\left(\mathrm{N}_{2} \mathrm{O}\right)$ emissions and account for $75 \%$ to $80 \%$ of the emission from agriculture (FAO, 2006). $\mathrm{CH}_{4}$ and $\mathrm{N}_{2} \mathrm{O}$ are greenhouse gases (GHG) with global warming potentials of 23 and 296 times that of $\mathrm{CO}_{2}$, respectively (IPCC, 2007). About $94 \%$ of global anthropogenic emissions of ammonia $\left(\mathrm{NH}_{3}\right)$ to the atmosphere originate from the agricultural sector of which close to $64 \%$ is associated with livestock management $(\boldsymbol{F A O}, 2006)$. Excessive levels of $\mathrm{NH}_{3}$ emissions contribute to eutrophication and acidification of water, soils and ecosystems (Schuurkes and Mosello, 1988). In addition to the global warming potential of the greenhouse gases, ammonia emissions 
contribute to global warming when the ammonia is converted to nitrous oxide (Berg, 1999; Sommer et al., 2000).

Manure is animal excreta (feces and urine) collected from animal buildings. Whereas slurry is a mixture of scraped animal excreta and flushing water and is collected from animal buildings. Hence, slurry is a mixture of manure and water. On the other hand, litter is animal excreta and bedding material collected from animal buildings (Samer, 2011a). Liquid manure storage facilities are sources of gaseous emissions of $\mathrm{NH}_{3}$ and greenhouse gases especially $\mathrm{CH}_{4}$ and $\mathrm{N}_{2} \mathrm{O}$. Additives can reduce gaseous emissions from swine waste lagoons and pits. The additives have the potential to reduce methane emissions from anaerobic swine lagoons (Shah and Kolar, 2012). Different materials for covering liquid manure storage facilities have been investigated and are in use for mitigating odor and ammonia emissions (Sommer et al., 1993; Williams, 2003). These materials abate also methane and nitrous oxide emissions. Different materials for covering liquid manure storage facilities to reduce gaseous emissions were investigated on laboratory scale: perlite, lightweight expanded clay aggregate and chopped straw - both individually and combined with lactic acid or saccharose, respectively (Berg et al., 2006a). Manipulating the balance between ammonia and ammonium by lowering the $\mathrm{pH}$-value of slurry is another measure to reduce emissions (Stevens et al., 1989; Oenema and Velthof, 1993; Hendriks and Vrielink, 1997; Kroodsma and Ogink, 1997; Martinez et al., 1997; Beck and Burton, 1998; Pedersen, 2003).

Ammonia and methane emissions can be controlled by $\mathrm{pH}$-value. Manipulating the $\mathrm{pH}$-value of slurry has an effect on the balance between ammonia and ammonium. The $\mathrm{pH}$-values of untreated slurries range between 7 up to 8 usually. Lowering the $\mathrm{pH}$ reduces the gaseous emission. From former investigations it is known that a slurry $\mathrm{pH}$ around 5.5 can reduce ammonia emission by 80 to 90\% (Al-Kanani et al., 1992; Berg et al., 2006a,b; Husted et al., 1991; Li et al., 2006; Pain et al., 1990; Stevens et al., 1989). A slurry $\mathrm{pH}$ below 4.5 nearly avoids ammonia emission (Hartung and Phillips, 1994). The $\mathrm{pH}$-value influences the activities of microorganisms. Higher methane production occurs, when the $\mathrm{pH}$ value is between 6 and 7 (Lay et al., 1997). A slurry pH below 6 is nec- 
essary to reduce methane emission and below 5 impede methane formation (Berg et. al, 2006a,b).

Whereas the use of inorganic acids has several disadvantages, using organic acids is a promising possibility to reduce methane, nitrous oxide and ammonia emissions (Berg and Hoernig, 1997; Berg and Pazsiczki, 2003; Berg, 2003). Wheeler et al. (2011a) stated that amendments can be practical and cost-effective for reducing $\mathrm{NH}_{3}$ and $\mathrm{GHG}$ emissions from dairy manure. They found that amendment products that act as microbial digest, oxidizing agent, masking agent or adsorbent significantly can reduce $\mathrm{NH}_{3}$ by more than $10 \%$. Whereas, microbial digest/enzymes with nitrogen substrate appeared effective in reducing $\mathrm{CH}_{4}$ fluxes. For both $\mathrm{CH}_{4}$ and $\mathrm{CO}_{2}$ fluxes, aging the manure slurry for 30 days can significantly reduce gas production. Reinhardt-Hanisch (2008) mentioned that the implementation of urease inhibitors is effective in reducing ammonia emissions from cattle and pig slurry. Wheeler et al. (2011b) stated that some amendments reduced odor emission depending on the storage period. Previous studies have evaluated additives for reducing gaseous emissions from manure in laboratory using glass jars or plexiglass tanks and a multi-gas monitor (Wheeler et al., 2011c; Reinhardt-Hanisch, 2008; Berg et al., 2006b).

Mathematical models and computer programs were developed to be implemented in constructing manure tanks and manure handling systems (Samer et al., 2011a, 2008a) as well as biogas plants (Samer, 2010), whereas the location of such systems in the farm vicinity was specified to be downwind to avoid gas transmission to the different farm facilities with a specified minimum distance between the farm and any adjacent residential communities, roads and ecosystems (Samer et al., 2008b). On the other hand, manure pits for temporary manure storage in livestock buildings form another effective source of gaseous emissions as shown in the different emissions inventories (Samer, 2013a). Airflow profiles affect the gas emission rates which increase with the increasing air volumetric flow rates and air velocities, where free air streams allow more gas release through convection mass transfer (Samer et al., 2011a; Samer, 2012). Additionally, gaseous emissions increase with increasing temperatures (Samer et al., 2012, 2011b; Samer, 2011b). The implemen- 
tation of proper waste management which is safe to the surroundings fulfils the green building specifications (Samer, 2013b).

The hypothesis of this study was: treating manure with acidic liquid biowastes (e.g. wastes of citrus, orange and milk industries) will reduce gaseous emissions, where the organic acids in the acidic liquid biowastes will reduce the $\mathrm{pH}$ of manure which consequently mitigates gaseous emissions. Eventually, this process is an integrated waste management of both manure and acidic liquid biowastes. Therefore, the objective of this study was to investigate the possibility of reducing gas emissions $\left(\mathrm{CH}_{4}\right.$, $\mathrm{N}_{2} \mathrm{O}$ and $\mathrm{NH}_{3}$ ) from dairy manure by adding low-pH biowastes (whey and waste of citrus and orange juices industry).

\section{MATERIALS AND METHODS}

\section{Collecting manure}

The fresh raw manure was collected randomly from dairy cows (female, 3 years, $580 \mathrm{Kg}$ ) holding pen unit.

\section{Manure analyses}

The $\mathrm{pH}$ and the temperature were measured using a $\mathrm{pH}$ meter (Jenway 3520, Staffordshire, UK). Total solids (TS), volatile solid (VS) and ash (Table 1) were determined using the standard methods (EPA, METHOD 1684, 2001) using muffle furnace (Ney Tech, Vulcan D-550, York, USA).

Table (1): Chemical composition of fresh manure.

\begin{tabular}{lc}
\hline Parameter & Value \\
\hline TS (\%) & 16.92 \\
VS (\%) & 12.97 \\
Ash (\%) & 4.02 \\
Organic carbon (\% from VS) & 44.63 \\
Total Nitrogen & 1.6 \\
C:N ratio & $25: 1$ \\
pH & 7.13 \\
\hline
\end{tabular}

\section{Slurry preparation}

The collected raw manure was homogenized by propeller mixer for 30 minutes. Afterwards, manure was poured in a tank and then whey was 
added and mixed with the dairy manure. Similarly, these procedures were conducted to mix manure with waste of citrus or orange juices industry.

\section{Experiments}

The experiments were carried out through two phases: preparatory experiments and laboratory experiments which were the main experiments.

\subsection{Preparatory experiments}

Pre-experiments were carried out to ascertain the relationship between the amount of the added biowastes and the $\mathrm{pH}$-value. For this purpose different biowaste: manure ratio $(1: 4,1: 3,1: 2$ and 1:1) were investigated. The $\mathrm{pH}$-values were measured over a period of 24 hours. Samples of dairy manure were mixed with whey, waste of citrus or orange juices industry with different ratios. Whey collected from milk industries was a mixture of whey sucralose and whey protein beverages $(\mathrm{pH}=3.9)$. On the other hand, waste of citrus juice industry contained sodium citrate and sodium acetate $(\mathrm{pH}=3.6)$. Similarly, waste of orange juice industry contained sodium citrate and sodium acetate but with different acidity $(\mathrm{pH}=3.75)$.

The $\mathrm{pH}$ and temperature of the mixture were measured using a $\mathrm{pH} / \mathrm{ION}$ Meter. This procedure allowed the determination of the best treatment specifications (biowaste:manure ratio, and $\mathrm{pH}$ of the mixture), where this procedure should be conducted with any new additive and before the main experiments. All preparatory experiments were carried out under the same laboratory conditions (i.e. lab temperature of $25^{\circ} \mathrm{C}$ approximately), respectively.

\subsection{Main experiments}

\subsubsection{Experimental set up}

A batch aerobic system was designed and implemented in this study. The main experiment tools consist of: flask, temperature control and gas measurement system. A 2.2-liter $(\varnothing=18 \mathrm{~cm})$ wide neck reaction Pyrex flask (Scilabware, FR2LF, Staffordshire, UK) was used and plugged (just during the measurements) with tightly Teflon cap equipped and gas outlet connected to the multi-gas monitor (Fig.1).

The temperature was controlled using a thermostatic water bath (Raypa, BAD-12, Barcelona, Spain) and maintained at $38 \pm 0.3^{\circ} \mathrm{C}$ in order to simulate the toughest weather conditions as the gas emissions increase with 
the increasing temperatures. The gas concentrations of methane $\left(\mathrm{CH}_{4}\right)$, nitrous oxide $\left(\mathrm{N}_{2} \mathrm{O}\right)$ and ammonia $\left(\mathrm{NH}_{3}\right)$ were measured using an infrared photo-acoustic analyzer (INNOVA 1412, Innova AirTech Instruments, Ballerup, Denmark) once a day.

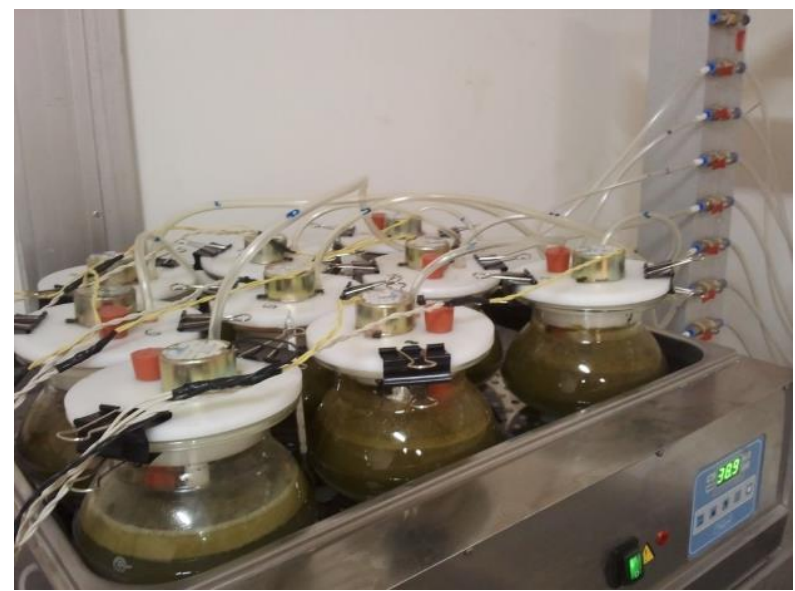

Figure (1): The experimental set-up.

\subsubsection{Experimental design}

A series of laboratory experiments using $2200 \mathrm{ml}$ flasks were performed in batch operation mode to investigate the influence of acidic liquid biowastes on $\mathrm{CH}_{4}, \mathrm{~N}_{2} \mathrm{O}$ and $\mathrm{NH}_{3}$ emissions. Each flask was fed with $800 \mathrm{~g}$ of fresh dairy manure (M) mixed with $800 \mathrm{ml}$ acidic liquid biowaste (B): as either whey $(\mathrm{P})$, which is Treatment 1 with 3 replicates; waste of citrus juice industry (C), which is Treatment 2 with 3 replicates; or waste of orange juice industry $(\mathrm{O})$, which is Treatment 3 with 3 replicates. The control sample was a mixture of dairy manure and water (W) which is Treatment 4 . The diameter of the sample surface area, after the flasks were filled, was equal to $13.7 \mathrm{~cm}$ approximately. Tables 2 and 3 present the initial composition of all flasks used in the study.

One of the most important factors affecting the emission flow rates is the temperature. The optimum temperature for most of involved bacteria groups is the range of $35-40^{\circ} \mathrm{C}$. Therefore, $38^{\circ} \mathrm{C}$ was selected as optimum temperature of bacterial activities as well as to simulate the toughest climatic conditions in summer where the gas emissions increase dramatically. 


\section{Table (2): Experimental design of the treatments and their replicates.}

\begin{tabular}{|c|c|c|c|c|c|c|c|c|}
\hline \multirow[t]{2}{*}{ Treatment } & \multirow[t]{2}{*}{ Replicate } & \multirow[t]{2}{*}{ Flask } & \multirow[t]{2}{*}{ M:W:P:C:O } & M & $\mathrm{W}$ & B & $\begin{array}{c}\text { Total } \\
\text { Volume }\end{array}$ & $\begin{array}{l}\text { Total } \\
\text { Mass }\end{array}$ \\
\hline & & & & g & $\mathrm{ml}$ & $\mathrm{ml}$ & $\mathrm{ml}$ & $g$ \\
\hline \multirow{3}{*}{ Treatment 1} & Replicate 1 & $\mathrm{~F} 1$ & 1:0:1:0:0 & 800 & 0 & 800 & 1867 & 1867.24 \\
\hline & Replicate 2 & $\mathrm{~F} 2$ & 1:0:1:0:0 & 800 & 0 & 800 & 1867 & 1867.20 \\
\hline & Replicate 3 & F3 & 1:0:1:0:0 & 800 & 0 & 800 & 1867 & 1867.27 \\
\hline \multirow{3}{*}{ Treatment 2} & Replicate 1 & $\mathrm{~F} 4$ & 1:0:0:1:0 & 800 & 0 & 800 & 1867 & 1867.53 \\
\hline & Replicate 2 & F5 & 1:0:0:1:0 & 800 & 0 & 800 & 1867 & 1867.55 \\
\hline & Replicate 3 & F6 & 1:0:0:1:0 & 800 & 0 & 800 & 1867 & 1867.61 \\
\hline \multirow{3}{*}{ Treatment 3} & Replicate 1 & F7 & 1:0:0:0:1 & 800 & 0 & 800 & 1867 & 1867.65 \\
\hline & Replicate 2 & F8 & $1: 0: 0: 0: 1$ & 800 & 0 & 800 & 1867 & 1867.61 \\
\hline & Replicate 3 & F9 & 1:0:0:0:1 & 800 & 0 & 800 & 1867 & 1867.72 \\
\hline $\begin{array}{c}\text { Treatment } 4 \\
\text { (Control) }\end{array}$ & - & F10 & 1:1:0:0:0 & 800 & 800 & 0 & 1867 & 1867.12 \\
\hline
\end{tabular}

Table (3): Initial chemical composition of the treatments and their replicates.

\begin{tabular}{|c|c|c|c|c|c|c|c|c|}
\hline \multirow{2}{*}{ Treatment } & \multirow{2}{*}{ Replicate } & \multirow{2}{*}{ Flask } & $\mathrm{TS}$ & VS & Ash & Organic carbon & \multirow{2}{*}{$\begin{array}{l}\mathrm{C}: \mathrm{N} \\
\text { ratio }\end{array}$} & \multirow{2}{*}{$\begin{array}{c}\mathrm{pH} \\
\text { Value }\end{array}$} \\
\hline & & & $\%$ & $\%$ & $\%$ & $\%$ from VS & & \\
\hline \multirow{3}{*}{ Treatment 1} & Replicate 1 & $\mathrm{~F} 1$ & 8.73 & 6.18 & 2.55 & 44.80 & $24.6: 1$ & 5.34 \\
\hline & Replicate 2 & $\mathrm{~F} 2$ & 8.65 & 5.99 & 2.66 & 44.76 & 24.8:1 & 5.36 \\
\hline & Replicate 3 & F3 & 8.72 & 6.10 & 2.62 & 44.78 & $24.7: 1$ & 5.35 \\
\hline \multirow{3}{*}{ Treatment 2} & Replicate 1 & $\mathrm{~F} 4$ & 8.42 & 6.53 & 1.89 & 44.91 & $25.2: 1$ & 4.87 \\
\hline & Replicate 2 & F5 & 7.95 & 6.38 & 1.57 & 44.84 & $25.1: 1$ & 4.91 \\
\hline & Replicate 3 & F6 & 8.49 & 6.41 & 2.08 & 44.87 & $25.1: 1$ & 4.85 \\
\hline \multirow{3}{*}{ Treatment 3} & Replicate 1 & F7 & 8.51 & 6.58 & 1.93 & 45.15 & $25.3: 1$ & 4.97 \\
\hline & Replicate 2 & F8 & 8.43 & 6.42 & 2.01 & 45.18 & $25.1: 1$ & 5.02 \\
\hline & Replicate 3 & F9 & 8.54 & 6.45 & 2.09 & 45.23 & $25.2: 1$ & 4.99 \\
\hline $\begin{array}{c}\text { Treatment } 4 \\
(\text { Control })\end{array}$ & - & $\mathrm{F} 10$ & 7.92 & 5.89 & 2.03 & 44.63 & $25.0: 1$ & 7.13 \\
\hline
\end{tabular}

\subsubsection{General procedures}

The investigations were carried out in the laboratory. The treatments were replicated 3 times. Dairy manure was stored in containers/flasks with a capacity of 2.21 each. The dry matter content of the manure was 
$16.9 \%$ and was reduced to $10 \%$ when treated with acidic liquid biowastes having high water contents of at least $95 \%$. The storage period was 180 days. Manure was treated with whey, where this was the first treatment. The second manure treatment was with waste of citrus juice industry. The third manure treatment was with waste of orange juice industry. Hence, three treatments, three replicates each, and one control were adopted. Therefore, ten flasks were used. The slurry (manure treated with acidic liquid biowastes having high water contents) was stored in open flasks which were closed and ventilated only during measurement, i.e. ventilated chamber method. In other words, the flasks were open permanently, closed and ventilated only during the measurement of headspace gas concentrations which is the dynamic chamber method. The ventilation rate during measurements was adjusted so that the air in the headspace always was changed one time per minute.

The capacity is $2200 \mathrm{ml}$ for each flask each. At the beginning of the investigations the headspace in each flask was about $333 \mathrm{ml}$ for the control and all treated samples. During the investigation period, the headspace was increasing because of the evaporation. The ventilation rate during the measurements was adjusted accordingly so that the air in the headspace always was changed one time per minute.

The Total Kjeldahl Nitrogen (TKN) and Total Ammoniacal Nitrogen (TAN) were measured in slurry by chemical analysis (according to DIN EN 25663 and DIN 38406-E5-2, respectively) at the beginning and the end of the investigation period. The room temperature was continuously measured throughout the experiments. However, all flasks were controlled using the water bath system to a constant temperature of $38.0 \pm 0.3^{\circ} \mathrm{C}$. The $\mathrm{pH}$-value of slurry was daily measured $2 \mathrm{~cm}$ below the surface and $2 \mathrm{~cm}$ above the base (in the sediments) of the slurry flask. The airflow rates were measured through flasks' headspace using airflow meters.

The results of the different treatments and their replicates were compared with each other and with the control sample, i.e. the untreated slurry. The statistical analysis was carried out using SAS v.9.2 (SAS Institute, Inc., Cary, N.C.). The comparisons of the mean values were made by using the t-test and the Wilcoxon test at the 0.05 probability level. 


\section{RESULTS AND DISCUSSION \\ 1. Preparatory experiments}

The results of the pre-experiments showed that the $\mathrm{pH}$-values subjected to the biowaste: manure ratio of $1: 4,1: 3,1: 2$ and $1: 1$, were $6,5,4.5$ and 4 for waste of citrus juice industry; 6.4, 5.3, 4.7 and 4.2 for waste of orange juice industry; and 6.9, 5.8, 5 and 4.6 for whey, respectively. This procedure allowed the determination of the best treatment specifications (biowaste: manure ratio, and $\mathrm{pH}$ of the mixture), where these preparatory experiments recommended a mixture ratio of $1: 1$ with a significant difference at the 0.05 probability level.

\section{Main experiments}

The trend of the main experiments is quantifying the gas concentrations from the different treatments using the gas detection system, measuring the $\mathrm{pH}$-values of the different treatments and their replicates and then comparing the results to determine which treatment is the most effective in reducing the emissions of $\mathrm{CH}_{4}, \mathrm{~N}_{2} \mathrm{O}$ and $\mathrm{NH}_{3}$.

\subsection{Post-treatment manure properties}

The results of manure analysis showed that the manure chemical composition have been significantly changed in comparison to the initial chemical composition. For instance, the $\mathrm{C}: \mathrm{N}$ ratio had a special case where adding whey (Treatment 1) to manure decreased the ratio (Table 3) where the added whey contains protein which increased the $\mathrm{N}$ content and consequently decreased the $\mathrm{C}: \mathrm{N}$ ratio. Table 3 showed that manure treatment with waste of citrus juice was the most effective in decreasing the $\mathrm{pH}$-value of the resulting slurry. Although manure treatment with whey reduced significantly the $\mathrm{pH}$, but its effect was lower than the waste of citrus juice. The final chemical composition of the treatments and their replicates, presented in Table 4, showed that the $\mathrm{pH}$-value slightly increased in comparison to the initial $\mathrm{pH}$-values presented in Table 3. This can be explained by the continuous biochemical reactions as well as the biological activities in slurry which continued during the investigation period (180 days), where these results led to the anticipation that the daily gas concentrations would slightly increase with progress of the investigation. 
Table (4): Final chemical composition of the treatments and their replicates.

\begin{tabular}{|c|c|c|c|c|c|c|c|c|}
\hline \multirow{2}{*}{ Treatment } & \multirow{2}{*}{ Replicate } & \multirow{2}{*}{ Flask } & $\mathrm{TS}$ & VS & Ash & Organic carbon & \multirow{2}{*}{$\begin{array}{l}\mathrm{C}: \mathrm{N} \\
\text { ratio }\end{array}$} & \multirow{2}{*}{$\begin{array}{c}\mathrm{pH} \\
\text { Value }\end{array}$} \\
\hline & & & $\%$ & $\%$ & $\%$ & $\%$ from VS & & \\
\hline \multirow{3}{*}{ Treatment 1} & Replicate 1 & $\mathrm{~F} 1$ & 5.55 & 3.77 & 1.78 & 43.90 & $25.6: 1$ & 5.79 \\
\hline & Replicate 2 & $\mathrm{~F} 2$ & 5.48 & 3.44 & 2.04 & 43.81 & 25.9:1 & 5.71 \\
\hline & Replicate 3 & F3 & 5.29 & 3.79 & 1.50 & 43.89 & 25.8:1 & 5.68 \\
\hline \multirow{3}{*}{ Treatment 2} & Replicate 1 & $\mathrm{~F} 4$ & 5.13 & 4.01 & 1.12 & 44.55 & $25.5: 1$ & 5.31 \\
\hline & Replicate 2 & F5 & 4.83 & 3.92 & 0.91 & 44.58 & $25.4: 1$ & 5.25 \\
\hline & Replicate 3 & F6 & 5.23 & 3.96 & 1.27 & 44.63 & $25.5: 1$ & 5.21 \\
\hline \multirow{3}{*}{ Treatment 3} & Replicate 1 & F7 & 5.51 & 4.11 & 1.4 & 44.21 & $26.0: 1$ & 5.40 \\
\hline & Replicate 2 & F8 & 5.21 & 3.94 & 1.27 & 44.14 & 25.8:1 & 5.45 \\
\hline & Replicate 3 & F9 & 5.15 & 3.99 & 1.16 & 44.17 & 26.0:1 & 5.51 \\
\hline Treatment 4 & - & F10 & 6.01 & 3.12 & 2.89 & 43.03 & $26.9: 1$ & 7.35 \\
\hline
\end{tabular}

\subsection{The pH-values}

The mean values over the whole investigation period show the differences in reducing the manure $\mathrm{pH}$ (Table 5), where each flask was observed 180 times (i.e. daily over a period of 180 days). Furthermore, studying the course measurements of the $\mathrm{pH}$-values over the investigation period provides a complete evaluation. Figure 2 shows the results of the course measurements of the $\mathrm{pH}$-values from the different treatments. The $\mathrm{pH}$-values increased slightly through the 180 days of investigations because of the continuous microbial activities. All treatments with whey and waste of citrus and orange juices industry were able to reduce manure $\mathrm{pH}$. However, waste of citrus juice industry was the most effective additive in reducing $\mathrm{pH}$ of the treated manure with an average $\mathrm{pH}$-value of 4.94. Additionally, waste of orange juice industry showed similar effect on manure $\mathrm{pH}$, with an average value of 5.08. Although, the differences between both additives were insignificant (difference at the 0.05 probability level), waste of citrus juice industry was able to achieve the lowest manure $\mathrm{pH}$ compared with other treatments (Table 5). Whey was able to reduce manure $\mathrm{pH}$ achieving an average $\mathrm{pH}$-value of 5.53 which is higher than the other additives, where the differences to the other additives were significant at the 0.05 probability level. The control (mixture of manure and water) had a mean $\mathrm{pH}$-value of 7.25. 
Table (5): Measurements of pH-values of the investigated samples.

\begin{tabular}{|c|c|c|c|c|}
\hline \multirow[b]{2}{*}{ Treatment } & \multirow[b]{2}{*}{ Replicate } & \multirow[b]{2}{*}{ Flask } & \multicolumn{2}{|c|}{$\mathrm{pH}-$ Value } \\
\hline & & & Mean & $\begin{array}{l}\text { Standard } \\
\text { Deviation }\end{array}$ \\
\hline \multirow{3}{*}{$\begin{array}{l}\text { Treatment 1: manure treated with } \\
\text { whey }\end{array}$} & Replicate 1 & $\mathrm{~F} 1$ & $5.55 \mathrm{~A}^{\mathrm{a}}$ & 0.32 \\
\hline & Replicate 2 & $\mathrm{~F} 2$ & $5.52 \mathrm{~A}$ & 0.41 \\
\hline & Replicate 3 & F3 & $5.51 \mathrm{~A}$ & 0.35 \\
\hline \multirow{3}{*}{$\begin{array}{l}\text { Treatment 2: manure treated with } \\
\text { waste of citrus juice industry }\end{array}$} & Replicate 1 & $\mathrm{~F} 4$ & $4.95 \mathrm{~B}$ & 0.33 \\
\hline & Replicate 2 & F5 & $4.94 \mathrm{~B}$ & 0.37 \\
\hline & Replicate 3 & F6 & $4.92 \mathrm{~B}$ & 0.29 \\
\hline \multirow{3}{*}{$\begin{array}{l}\text { Treatment 3: manure treated with } \\
\text { waste of orange juice industry }\end{array}$} & Replicate 1 & F7 & $5.05 \mathrm{~B}$ & 0.36 \\
\hline & Replicate 2 & F8 & $5.09 \mathrm{~B}$ & 0.31 \\
\hline & Replicate 3 & F9 & $5.10 \mathrm{~B}$ & 0.28 \\
\hline $\begin{array}{l}\text { Treatment 4: control, a mixture of } \\
\text { dairy manure and water }\end{array}$ & - & F10 & $7.25 \mathrm{C}$ & 0.19 \\
\hline
\end{tabular}

${ }^{a}$ Values with different letters have a significant difference at the 0.05 Probability level.

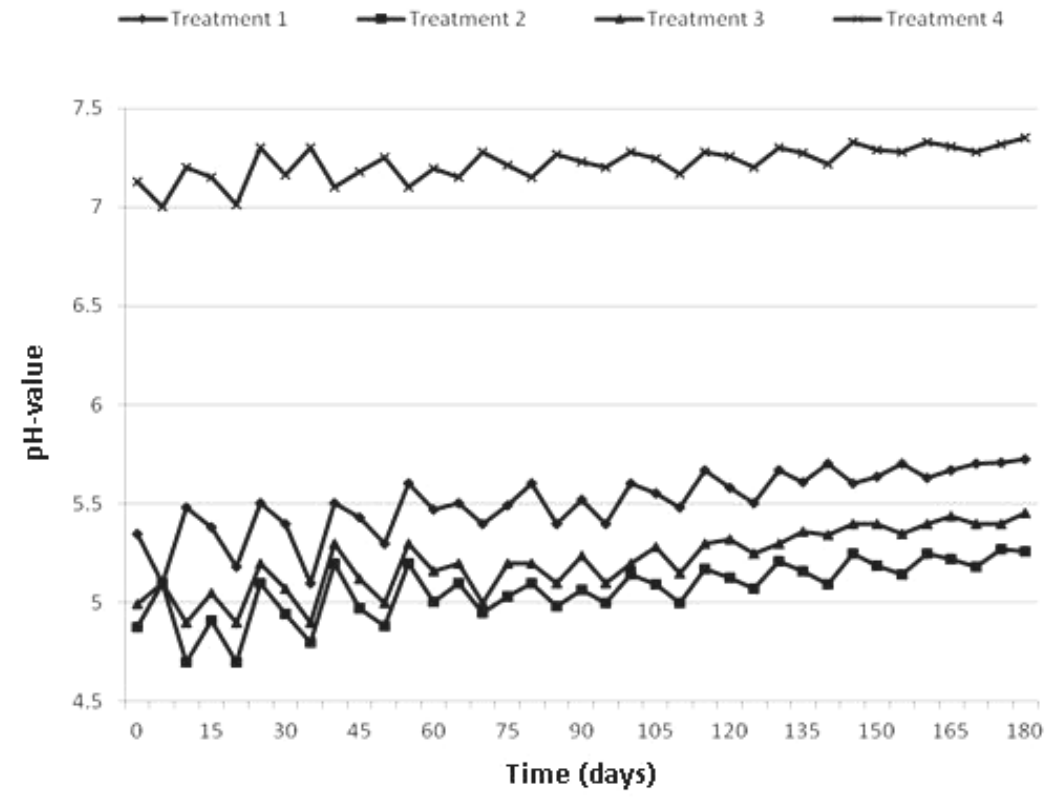

Figure (2): Results of course measurements of the $\mathrm{pH}$-values form the different treatments. 
The temperatures of the different flasks were kept constant to $38 \pm 0.3^{\circ} \mathrm{C}$ using a water bath instrumentation system, therefore the temperatures of the samples were similar and did not have an effect on the measured values. The $\mathrm{pH}$-values in sediments of the different flasks were average of 0.4 (treated) and 0.25 (control) lower than near the slurry surface (significant at the 0.05 probability level).2.3. Gas emissions

\subsubsection{Methane emissions}

Manure treatment with waste of citrus juice industry reduced $\mathrm{CH}_{4}$ concentrations to average $17.3 \mathrm{mg} \mathrm{CH} / \mathrm{m}^{3}$ (Table 6) which corresponds to a gas flux of $13 \mathrm{~g} / \mathrm{m}^{2}$ day with a mean reduction rate of $77.7 \%$, where this treatment reduced the $\mathrm{pH}$-value to less than 5. Similarly, manure treatment with waste of orange juice industry reduced $\mathrm{CH}_{4}$ concentrations to average $18 \mathrm{mg} \mathrm{CH} / \mathrm{m}^{3}$ which corresponds to a gas flux of $13.58 \mathrm{~g} / \mathrm{m}^{2}$ day with a mean reduction rate of $76.7 \%$, where this treatment reduced the $\mathrm{pH}$-value to slightly above than 5 . The differences between both treatments were insignificant at the 0.05 probability level. However, manure treatment with whey was less effective and reduced $\mathrm{CH}_{4}$ concentrations to average $23.2 \mathrm{mg} \mathrm{CH}_{4} \mathrm{~m}^{-3}$ which corresponds to a gas flux of $17.45 \mathrm{~g} / \mathrm{m}^{2}$ day with significant differences to both other treatments at the 0.05 probability level, where the mean reduction rate was about $70 \%$.

Table (6): Measurements of methane concentrations of the investigated samples.

\begin{tabular}{|c|c|c|c|c|c|}
\hline \multirow{2}{*}{ Treatment } & \multirow{2}{*}{ Replicate } & \multirow{2}{*}{ Flask } & \multicolumn{2}{|c|}{$\begin{array}{l}\text { Methane Concentration (mg } \\
\mathrm{CH}_{4} / \mathrm{m}^{3} \text { ) } \\
\end{array}$} & \multirow{2}{*}{$\begin{array}{l}\text { Number of } \\
\text { Observations }\end{array}$} \\
\hline & & & Mean & Standard Deviation & \\
\hline \multirow{3}{*}{$\begin{array}{l}\text { Treatment 1: manure treated with } \\
\text { whey }\end{array}$} & Replicate 1 & $\mathrm{~F} 1$ & $23.4 \mathrm{~A}^{\mathrm{a}}$ & 39.2 & 180 \\
\hline & Replicate 2 & $\mathrm{~F} 2$ & $23.1 \mathrm{~A}$ & 39.0 & 180 \\
\hline & Replicate 3 & F3 & $23.0 \mathrm{~A}$ & 38.9 & 180 \\
\hline \multirow{3}{*}{$\begin{array}{l}\text { Treatment 2: manure treated with } \\
\text { waste of citrus juice industry }\end{array}$} & Replicate 1 & $\mathrm{~F} 4$ & $17.5 \mathrm{~B}$ & 19.4 & 180 \\
\hline & Replicate 2 & F5 & $17.2 \mathrm{~B}$ & 19.2 & 180 \\
\hline & Replicate 3 & F6 & $17.1 \mathrm{~B}$ & 19.0 & 180 \\
\hline \multirow{3}{*}{$\begin{array}{l}\text { Treatment 3: manure treated with } \\
\text { waste of orange juice industry }\end{array}$} & Replicate 1 & F7 & $17.9 \mathrm{~B}$ & 19.9 & 180 \\
\hline & Replicate 2 & F8 & $18.0 \mathrm{~B}$ & 19.7 & 180 \\
\hline & Replicate 3 & F9 & $18.2 \mathrm{~B}$ & 19.5 & 180 \\
\hline $\begin{array}{l}\text { Treatment 4: control, a mixture of } \\
\text { dairy manure and water }\end{array}$ & - & F10 & $77.3 \mathrm{C}$ & 129 & 180 \\
\hline
\end{tabular}

${ }^{a}$ Values with different letters have a significant difference at the 0.05 probability level. 
The measured $\mathrm{CH}_{4}$ concentrations in the control sample (mixture of dairy manure and water) were average of $77.3 \mathrm{mg} \mathrm{CH} / 4 \mathrm{~m}^{3}$ which corresponds to a gas flux of $58.21 \mathrm{~g} / \mathrm{m}^{2}$ day. On the other hand, methane emissions from the same sample- varied widely during the whole period of investigation.

\subsubsection{Nitrous oxide emissions}

Manure treatment with waste of citrus juice industry reduced $\mathrm{N}_{2} \mathrm{O}$ concentrations to average $0.291 \mathrm{mg} \mathrm{N} \mathrm{N}_{2} \mathrm{O} / \mathrm{m}^{3}$ (Table 7) which corresponds to a gas flux of $0.219 \mathrm{~g} / \mathrm{m}^{2}$ day with a mean reduction rate of $36.9 \%$, where this treatment reduced the $\mathrm{pH}$-value to less than 5. Similarly, manure treatment with waste of orange juice industry reduced $\mathrm{N}_{2} \mathrm{O}$ concentrations to average $0.296 \mathrm{mg} \mathrm{N} 2 \mathrm{O} / \mathrm{m}^{3}$ which corresponds to a gas flux of $0.223 \mathrm{~g} / \mathrm{m}^{2}$ day with a mean reduction rate of $35.9 \%$, where this treatment reduced the $\mathrm{pH}$-value to slightly above than 5 . The differences between both treatments were insignificant at the 0.05 probability level. However, manure treatment with whey was less effective and reduced $\mathrm{N}_{2} \mathrm{O}$ concentrations to average $0.371 \mathrm{mg} \mathrm{N} 2 \mathrm{O} / \mathrm{m}^{3}$ which corresponds to a gas flux of $0.279 \mathrm{~g} / \mathrm{m}^{2}$ day with significant differences to both other treatments at the 0.05 probability level, where the mean reduction rate was about $19.5 \%$ only.

Table (7): Measurements of nitrous oxide concentrations of the investigated samples.

\begin{tabular}{|c|c|c|c|c|c|}
\hline \multirow{2}{*}{ Treatment } & \multirow{2}{*}{ Replicate } & \multirow[t]{2}{*}{ Flask } & \multicolumn{2}{|c|}{$\begin{array}{l}\text { Nitrous Oxide Concentration } \\
\left(\mathrm{mg} \mathrm{N}_{2} \mathrm{O} \mathrm{m}^{-3}\right) \\
\end{array}$} & \multirow{2}{*}{$\begin{array}{c}\text { Number of } \\
\text { Observations }\end{array}$} \\
\hline & & & Mean & Standard Deviation & \\
\hline \multirow{3}{*}{$\begin{array}{l}\text { Treatment 1: manure treated with } \\
\text { whey }\end{array}$} & Replicate 1 & $\mathrm{~F} 1$ & $0.369 \mathrm{~A}^{\mathrm{a}}$ & 0.552 & 180 \\
\hline & Replicate 2 & $\mathrm{~F} 2$ & $0.371 \mathrm{~A}$ & 0.549 & 180 \\
\hline & Replicate 3 & $\mathrm{~F} 3$ & $0.373 \mathrm{~A}$ & 0.551 & 180 \\
\hline \multirow{3}{*}{$\begin{array}{l}\text { Treatment 2: manure treated with } \\
\text { waste of citrus juice industry }\end{array}$} & Replicate 1 & $\mathrm{~F} 4$ & $0.290 \mathrm{~B}$ & 0.511 & 180 \\
\hline & Replicate 2 & F5 & $0.291 \mathrm{~B}$ & 0.517 & 180 \\
\hline & Replicate 3 & F6 & $0.292 \mathrm{~B}$ & 0.513 & 180 \\
\hline \multirow{3}{*}{$\begin{array}{l}\text { Treatment 3: manure treated with } \\
\text { waste of orange juice industry }\end{array}$} & Replicate 1 & F7 & $0.293 \mathrm{~B}$ & 0.520 & 180 \\
\hline & Replicate 2 & F8 & $0.295 \mathrm{~B}$ & 0.519 & 180 \\
\hline & Replicate 3 & F9 & $0.299 \mathrm{~B}$ & 0.522 & 180 \\
\hline $\begin{array}{c}\text { Treatment 4: control, a mixture of } \\
\text { dairy manure and water }\end{array}$ & - & F10 & $0.461 \mathrm{C}$ & 0.652 & 180 \\
\hline
\end{tabular}

${ }^{\text {a }}$ Values with different letters have a significant difference at the 0.05 probability level. 
The measured $\mathrm{N}_{2} \mathrm{O}$ concentrations in the control sample (mixture of dairy manure and water) were average of $0.461 \mathrm{mg} \mathrm{N} 2 \mathrm{O} / \mathrm{m}^{3}$ which corresponds to a gas flux of $0.347 \mathrm{~g} / \mathrm{m}^{2}$ day. On the other hand, nitrous oxide emissions -from the same sample- varied widely during the whole period of investigation.

\subsubsection{Ammonia emissions}

Manure treatment with waste of citrus juice industry reduced $\mathrm{NH}_{3}$ concentrations to average $3.35 \mathrm{mg} \mathrm{NH} / \mathrm{m}^{3}$ (Table 8) which corresponds to a gas flux of $2.523 \mathrm{~g} / \mathrm{m}^{2}$.day with a mean reduction rate of $86.7 \%$, where this treatment reduced the $\mathrm{pH}$-value to less than 5. Similarly, manure treatment with waste of orange juice industry reduced $\mathrm{NH}_{3}$ concentrations to average $3.43 \mathrm{mg} \mathrm{NH} / \mathrm{m}^{3}$ which corresponds to a gas flux of $2.581 \mathrm{~g} / \mathrm{m}^{2}$.day with a mean reduction rate of $86.3 \%$, where this treatment reduced the $\mathrm{pH}$-value to slightly above than 5 . The differences between both treatments were insignificant at the 0.05 probability level. However, manure treatment with whey was less effective and reduced $\mathrm{NH}_{3}$ concentrations to average $4.1 \mathrm{mg} \mathrm{NH} / \mathrm{m}^{3}$ which corresponds to a gas flux of $3.063 \mathrm{~g} / \mathrm{m}^{2}$.day with significant differences to both other treatments at the 0.05 probability level, where the mean reduction rate was about $83.8 \%$. The measured $\mathrm{NH}_{3}$ concentrations in the control sample (mixture of dairy manure and water) were average of $25.1 \mathrm{mg}$ $\mathrm{NH}_{3} / \mathrm{m}^{3}$ which corresponds to a gas flux of $18.9 \mathrm{~g} / \mathrm{m}^{2}$.day. On the other hand, ammonia emissions -from the same sample- varied widely during the whole period of investigation. Table 9 shows the Total Ammoniacal Nitrogen (TAN) and the Total Kjeldahl Nitrogen (TKN) of all slurry samples after storage, and the calculated absolute Total Nitrogen Losses (ATNL) of the slurry samples during storage on the basis of TKN before and after storage. The chemical analyses of the TAN and TKN (Table 9) confirmed the results of the measurements of gaseous nitrogen emissions. Initially, slurry (mixture of manure and water) had a TAN content of 3.16 $\mathrm{g} \mathrm{N} / \mathrm{kg}$ fresh mass and a TKN content of $5.06 \mathrm{~g} \mathrm{~N} / \mathrm{kg}$ fresh mass. The absolute nitrogen losses were calculated based on the TKN content. These values correspond to the measured total gaseous nitrogen emissions. 


\section{Table (8): Measurements of ammonia concentrations of the investi- gated samples.}

\begin{tabular}{|c|c|c|c|c|c|}
\hline \multirow[t]{2}{*}{ Treatment } & \multirow[t]{2}{*}{ Replicate } & \multirow[t]{2}{*}{ Flask } & \multicolumn{2}{|c|}{$\begin{array}{l}\text { Ammonia Concentration } \\
\left(\mathrm{mg} \mathrm{NH}_{3} \mathrm{~m}^{-3}\right) \\
\end{array}$} & \multirow{2}{*}{$\begin{array}{c}\text { Number of } \\
\text { Observations }\end{array}$} \\
\hline & & & Mean & Standard Deviation & \\
\hline \multirow{3}{*}{$\begin{array}{l}\text { Treatment 1: manure treated with } \\
\text { whey }\end{array}$} & Replicate 1 & $\mathrm{~F} 1$ & $4.01 \mathrm{~A}^{\mathrm{a}}$ & 5.21 & 180 \\
\hline & Replicate 2 & $\mathrm{~F} 2$ & $4.12 \mathrm{~A}$ & 5.29 & 180 \\
\hline & Replicate 3 & $\mathrm{~F} 3$ & $4.07 \mathrm{~A}$ & 5.18 & 180 \\
\hline \multirow{3}{*}{$\begin{array}{l}\text { Treatment 2: manure treated with } \\
\text { waste of citrus juice industry }\end{array}$} & Replicate 1 & $\mathrm{~F} 4$ & $3.35 \mathrm{~B}$ & 4.77 & 180 \\
\hline & Replicate 2 & F5 & $3.37 \mathrm{~B}$ & 4.39 & 180 \\
\hline & Replicate 3 & F6 & $3.33 \mathrm{~B}$ & 4.51 & 180 \\
\hline \multirow{3}{*}{$\begin{array}{l}\text { Treatment 3: manure treated with } \\
\text { waste of orange juice industry }\end{array}$} & Replicate 1 & F7 & $3.42 \mathrm{~B}$ & 4.98 & 180 \\
\hline & Replicate 2 & F8 & $3.41 \mathrm{~B}$ & 4.95 & 180 \\
\hline & Replicate 3 & F9 & $3.45 \mathrm{~B}$ & 4.87 & 180 \\
\hline $\begin{array}{l}\text { Treatment 4: control, a mixture of } \\
\text { dairy manure and water }\end{array}$ & - & F10 & $25.1 \mathrm{C}$ & 5.88 & 180 \\
\hline
\end{tabular}

${ }^{\text {a }}$ Values with different letters have a significant difference at the 0.05 probability level.

\section{Global warming potential}

The global warming potentials (GWP) of the different gases should be taken into consideration when evaluating the effects of greenhouse gas emissions from manure storage facilities. According to the IPCC (2007), the global warming potentials of $\mathrm{CH}_{4}$ and $\mathrm{N}_{2} \mathrm{O}$ are 23 and 296 times that of $\mathrm{CO}_{2}$, respectively. Regarding $\mathrm{NH}_{3}$, it is estimated that $1 \%$ of the deposited nitrogen emits as $\mathrm{N}_{2} \mathrm{O}$ (Houghton et al., 1997). Considering these different GWPs and the measured emission rates, $\mathrm{CH}_{4}$ is the predominant greenhouse gas emitted from liquid manure storage facilities (Fig. 3). The highest $\mathrm{N}_{2} \mathrm{O}$ emission occurred when manure surfaces become encrusted. Ammonia has barely an effect on global warming. However, ammonia emissions contribute to global warming when the ammonia is converted to nitrous oxide. Anyway, ammonia is a main source for eutrophication and acidification of water, soils and ecosystems.

Manure treatment with acidic liquid biowastes (waste of citrus, orange and milk industries) which contain organic acids, reduces the manure $\mathrm{pH}$ which inhibits the bacterial activities where most of the bacterial activi- 
ties impede at a $\mathrm{pH}$-value equal to 4.5 and, consequently, mitigates the gaseous emissions from manure.

\section{Table (9): Total Ammoniacal Nitrogen (TAN), Total Kjeldahl Nitro- gen (TKN) and Total Nitrogen Losses (ATNL).}

\begin{tabular}{clcccc}
\hline Treatment & Replicate & Flask & $\begin{array}{c}\text { TAN } \\
\text { (g N/kg } \\
\text { fresh mass) }\end{array}$ & $\begin{array}{c}\text { TKN } \\
\text { (g N/kg } \\
\text { fresh mass) }\end{array}$ & $\begin{array}{c}\text { ATNL } \\
(\mathrm{g})\end{array}$ \\
\hline \multirow{2}{*}{ Treatment 1: manure treated with } & Replicate 1 & F1 & 3.50 & 5.41 & 63 \\
& Replicate 2 & F2 & 3.46 & 5.37 & 61 \\
& Replicate 3 & F3 & 3.48 & 5.40 & 60 \\
\hline \multirow{2}{*}{ Treatment 2: manure treated with } & Replicate 1 & F4 & 2.73 & 4.81 & 51 \\
waste of citrus juice industry & Replicate 2 & F5 & 2.75 & 4.77 & 51 \\
\hline \multirow{2}{*}{$\begin{array}{c}\text { Replicate 3 } \\
\text { wreatment 3: manure treated with }\end{array}$} & Replicate 1 & F7 & 2.71 & 4.79 & 49 \\
\hline Treatment 4: control, a mixture of & Replicate 2 & F8 & 2.81 & 4.99 & 54 \\
dairy manure and water & Replicate 3 & F9 & 2.88 & 4.93 & 53 \\
\hline
\end{tabular}

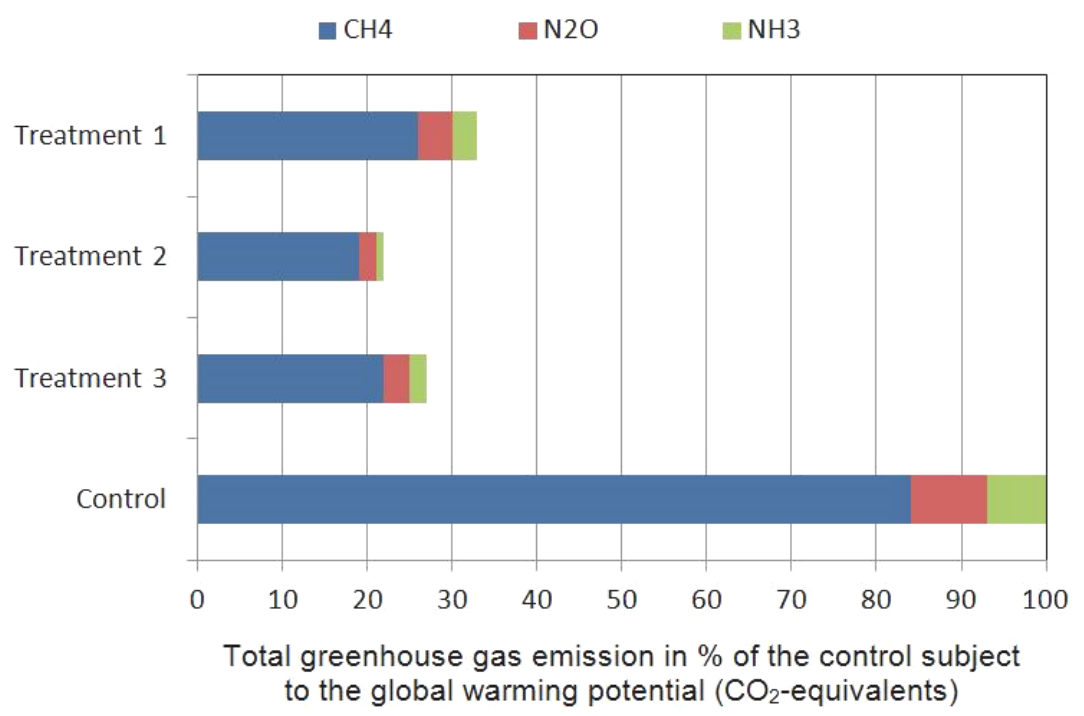

Figure (3): Total greenhouse gas emission of the different treatments subject to the global warming potential ( $\mathrm{CO}_{2}$-equivalents). 
Manure treatment with acidic liquid biowastes enabled high reduction rates of gaseous emissions from manure. However, it was noticed that the $\mathrm{pH}$-values slightly increased by about 0.4 with the progress of the investigations (through the 180 days of investigations), and consequently the gaseous emissions slightly increased with the progress of the investigations. This can be explained by the statement of Raghav et al. (2012) that the organic acids degrade with time. Nevertheless, manure treatment with acidic liquid biowastes is still effective in lowering manure $\mathrm{pH}$ and reducing greenhouse gases and ammonia emissions.

The results of this study agreed with the results of several studies (Stevens et al., 1989; Oenema and Velthof, 1993; Hendriks and Vrielink, 1997; Kroodsma and Ogink, 1997; Martinez et al., 1997; Beck and Burton, 1998; Pedersen, 2003) which concluded that manipulating the balance between ammonia and ammonium by lowering the $\mathrm{pH}$-value of slurry is a measure to reduce emissions. The results of this study confirmed the statements of several studies (Al-Kanani et al., 1992; Berg et al., 2006a,b; Husted et al., 1991; Li et al., 2006; Pain et al., 1990; Stevens et al., 1989) that a slurry $\mathrm{pH}$ around 5.5 can reduce ammonia emission by 80 to $90 \%$. Additionally, the results of this study agreed with those of Lay et al. (1997) and Berg et. al (2006a,b) that higher methane production occurs, when the $\mathrm{pH}$-value is between 6 and 7 and a slurry $\mathrm{pH}$ below 6 is necessary to reduce methane emission and below 5.0 causes a noticeable reduction of methane emissions, where the $\mathrm{pH}$-value influences the activities of microorganisms. On the other hand, the results of this study agreed with the statements of Berg and Hoernig (1997), Berg and Pazsiczki (2003) and Berg (2003) who stated that using organic acids is a promising possibility to reduce methane, nitrous oxide and ammonia emissions. However, the organic acids are expensive. Therefore, in this study, acidic liquid biowastes -containing organic acids- were implemented to manipulate the manure $\mathrm{pH}$, where the investigated biowastes are cheap and the costs are limited to transportation.

The implemented acidic liquid biowastes in this study have several advantages, which are: low-pH biomaterials, cheap where the costs are limited to transportation, and available from food industries. An additional advantage is developing an important usage for some of the biowastes of 
the food industries. This manure treatment is expected to produce a high value biofertilizer. Manure treated with biomaterials and then distributed as biofertilizer for the plants leads to avoiding the disadvantages of the mineral and inorganic additives which contaminate the soils and increase their salt contents. This treatment is expected to provide cost effective and safe biofertilizers (manure treated with different acidic liquid biowastes) free of soil contaminants with lower greenhouse gases and ammonia emissions. One key issue is that the effect of these biofertilizers on soils' structures, nutrients content, chemical and physical properties after being incorporated into soils, should be investigated thoroughly. Although the effect of treated manure with acidic liquid biowastes on soils' properties still unknown, these biowastes are simply biomaterials which are degradable in soils. Additionally, the used biowastes do neither contain heavy metals nor pollutants. Therefore, these biowastes are not expected to be soil contaminants. Anyway, further investigations should be carried out to discover their effects on soils.

Eventually, this process is an integrated waste management of both manure and acidic liquid biowastes of food industries. Important outcomes are complying with Kyoto Protocol by mitigating the emissions of greenhouse gases, and conforming to Gothenburg Protocol by abating the ammonia emissions which allow revising and updating the present emissions inventories when this emissions abatement technique is applied.

\section{Future developments}

Further future investigations are planned and will be carried out to determine the effectiveness of this technique to mitigate gas emissions from beef cattle, buffalo, sheep, goat, horse, pig and poultry manure. Other additives are planned to be investigated, such as the acidic biowastes of the of food/juice industries for the following materials: mandarin, grape fruit and peach juices. Furthermore, additional materials are under consideration such as: lignite, perlite and humate products. On the other hand, the results of this study will be further tested through on-farm experiments. The same procedures carried out through the laboratory experiments are planned to be conducted on-farm with full-scale experiments. This requires a small manure tank in a dairy farm to be treated with the biowastes recommended by the results of this study. Subsequently, the 
manure tank will be covered with a membrane cover similar to that used in biogas plants but under aerobic conditions, this will allow the accumulation of the gases under the cover where a tube will suck a sample to the multi-gas monitor to quantify the concentration of the different gases.

\section{CONCLUSIONS}

Lowering manure $\mathrm{pH}$ can reduce methane, nitrous oxide and ammonia emissions. Manure treatment with acidic liquid biowastes (waste of citrus, orange and milk industries) which contain organic acids, reduces the manure $\mathrm{pH}$ which inhibits the bacterial activities and, consequently, mitigates the gaseous emissions from manure. Manure treatment with acidic liquid biowastes enabled high reduction rates of gaseous emissions from manure. However, the $\mathrm{pH}$-values slightly increased with the progress of the investigations (through the 180 days of investigations). This can be explained by the fact that the organic acids degrade with time. Nevertheless, manure treatment with acidic liquid biowastes is still effective in lowering manure $\mathrm{pH}$ and reducing greenhouse gases and ammonia emissions.

Manure treatment with waste of citrus juice industry was the most effective manure treatment among the investigated treatments. Additionally, manure treatment with waste of orange juice industry was effective in reducing methane, nitrous oxide, and ammonia emissions. Although whey was effective in reducing the gaseous emissions, it was the less effective manure treatment. Eventually, the results of this study recommended manure treatment with acidic liquid biowastes as an effective emissions abatement technique.

Considering the different global warming potentials and the measured emission rates, methane is the predominant greenhouse gas emitted from liquid manure storage facilities. The total greenhouse gas emission in percentage of the control sample calculated on the basis of the global warming potential $\left(\mathrm{CO}_{2}\right.$-equivalents) showed that manure treatment with waste of citrus juice industry delivered the lowest $\mathrm{CO}_{2}$-equivalents, whereas manure treatment with waste of orange juice industry delivered slightly higher $\mathrm{CO}_{2}$-equivalents. However, manure treatment with whey delivered the highest $\mathrm{CO}_{2}$-equivalents among the three additives. 


\section{REFERENCES}

Al-Kanani, T., E. Akochi, A.F. Mackenzie, I. Alli, and S. Barrington. 1992. Organic and inorganic amendments to reduce ammonia losses from liquid hog manure. Journal of Environmental Quality, 21, 709-715.

Beck, J., Burton, C., 1998. Manure treatment techniques in Europeresult of a EU Concerted Action. In: Proceedings of the International Conference on Agricultural Engineering, AgEng 98, Oslo, Norway, August 24-27, pp. 211-212.

Berg, W., 2003. Reducing ammonia emissions by combining covering and acidifying liquid manure. In: Proceedings of the Third International Conference on Air Pollution from Agricultural Operations, Raleigh, NC, USA, October 12-15, pp. 174-182.

Berg, W., 1999. Technology assessment-livestock management. Anim. Res. Dev. 50, 98-109.

Berg, W., Hoernig, G., 1997. Emission reduction by acidification of slurry-investigations and assessment. In: Voormans, J.A.M., Monteny, G.J. (Eds.), Proceedings of the International Symposium on Ammonia and Odour Control from Animal Production Facilities, Vinkeloord, The Netherlands, October 6-10, pp. 459-466.

Berg, W., Pazsiczki, I., 2003. Reducing emissions by combining slurry covering and acidifying. In: Proceedings of the International Symposium on Gaseous and Odour Emissions from Animal Production Facilities, Horsens, Denmark, June 1-4, pp. 460-468.

Berg, W., R. Brunsch, and I. Pazsiczki. 2006a. Greenhouse gas emissions from covered slurry compared with uncovered during storage. Agriculture, Ecosystems and Environment, 112 (2-3), 129-134.

Berg, W., M. Türk, and J. Hellebrand. 2006b. Effects of Acidifying Liquid Cattle Manure with Nitric or Lactic Acid on Gaseous Emissions. Workshop on Agricultural Air Quality - State of the Science. Potomac, MD, USA. 5-8 June 2006. 492-498.

FAO. 2006. Livestock's role in climate change and air pollution. Available at: ftp://ftp.fao.org/docrep/fao/010/a0701e/A0701E03.pdf. Accessed December 2010. 
Hartung, J. and V.R. Phillips. 1994. Control of gaseous emissions from livestock buildings and manure stores. Journal Agricultural Engineering Research, 57, 173-189.

Hendriks, J.G.L., Vrielink, M.G.M., 1997. Reducing ammonia emission from pig houses by adding or producing organic acids in pig slurry. In: Voormans, J.A.M., Monteny, G.J. (Eds.), Proceedings of the International Symposium on Ammonia and Odour Control from Animal Production Facilities, Vinkeloord, The Netherlands, October 6-10, pp. 493-501.

Houghton, J.T., L.G. Meira Filho, B. Lim, K. Treanton, I. Mamaty, Y. Bonduki, D.J. Griggs, B.A. Callender (Eds.). 1997. Revised 1996 IPCC Guidelines for National Greenhouse Gas Inventories. IPCC/OECD/IEA. UK Meteorological Office, Bracknell.

Husted, S., L.S. Jensen, and S.S. Jorgensen. 1991. Reducing ammonia loss from cattle slurry by the used of acidifying additives: the role of the buffer system. Journal of the Science of Food and Agriculture, 57, 335-349.

IPCC. 2007. Climate Change 2007: Mitigation. Contribution of Working Group III to the $4^{\text {th }}$ Assessment Report of the Intergovernmental Panel on Climate Change. B. Metz, O. R. Davidson, P. R. Bosch, R. Dave, and L. A. Meyer, eds. Cambridge University Press, Cambridge, United Kingdom and New York, NY, USA.

Kroodsma, W., Ogink, N.W.M., 1997. Volatile emissions from cow cubicle houses and its reduction by immersion of the slats with acidified slurry. In: Voormans, J.A.M., Monteny, G.J. (Eds.), Proceedings of the International Symposium on Ammonia and Odour Control from Animal Production Facilities, Vinkeloord, The Netherlands, October 6-10, pp. 475-483.

Lay, J.J., Y.Y. Li, and T. Noike. 1997. Influences of $\mathrm{pH}$ and moisture content on the methane production in high-solids sludge digestion. Water Research, 31 (6), 1518-1524.

Li, H., H. Xin, and R.T. Burns. 2006. Reduction of ammonia emission from stored poultry manure using additives: zeolite, $\mathrm{Al}^{+}$clear, Ferix-3, and PLT. ASAE Paper No. 064188, 2006 ASABE Annual International Meeting, Portland, OR, USA. 
Martinez, J., Jolivet, J., Guiziou, F., Langeoire, G., 1997. Ammonia emissions from pig slurries: evaluation of acidification and the use of additives in reducing losses. In: Voormans, J.A.M., Monteny, G.J. (Eds.), Proceedings of the International Symposium on Ammonia and Odour Control from Animal Production Facilities, Vinkeloord, The Netherlands, October 6-10, pp. 485-492.

Oenema, O., Velthof, G.L., 1993. Denitrification in nitric-acid-treated cattle slurry during storage. Neth. J. Agric. Sci. 41, 63-80.

Pain, B.F., R.B. Thompson, Y.J. Rees, and J.H. Skinner. 1990. Reducing gaseous losses of nitrogen from cattle slurry applied to grassland by the use of additives. Journal of the Science of Food and Agriculture, 50, 141-153.

Pedersen, P., 2003. Reduction of gaseous emissions from pig houses by adding sulphuric acid to the slurry. In: Proceedings of the International Symposium on Gaseous and Odour Emissions from Animal Production Facilities, Horsens, Denmark, June 1-4, pp. 257-263.

Raghav R., N. Yadav, G. Tyagi, D.K. Jangir, R. Mehrotra, R. Ganesan, E.S. Rajagopal. 2012. Degradation studies of organic acids in commercially packed fruit juices: A reverse phase high performance liquid chromatographic approach. International Journal of Food Engineering, DOI: 10.1515/1556-3758.1821.

Reinhardt-Hanisch, A. 2008. Grundlagenuntersuchungen zur Wirkung neuartiger Ureaseinhibitoren in der Nutztierhaltung (Basic research on the effects of novel urease inhibitors in animal housing). $\mathrm{PhD}$ diss. Stuttgart, Germany: University of Hohenheim.

Samer, M. 2013a. Emissions inventory of greenhouse gases and ammonia from livestock housing and manure management. Agricultural Engineering International: CIGR Journal, Vol. 15(3): 29 - 54.

Samer, M. 2013b. Towards the implementation of the Green Building concept in agricultural buildings: a literature review. Agricultural Engineering International: CIGR Journal, Vol. 15(2): 25-46.

Samer, M., C. Ammon, C. Loebsin, M. Fiedler, W. Berg, P. Sanftleben, and R. Brunsch. 2012. Moisture balance and tracer gas technique for ventilation rates measurement and greenhouse 
gases and ammonia emissions quantification in naturally ventilated buildings. Building and Environment, Vol. 50(4): 10-20.

Samer, M. 2012. Effect of airflow profile on reducing heat stress, enhancing air distribution and diluting gaseous concentrations in dairy barns. Misr Journal of Agricultural Engineering, Vol. 29(2): 837-856.

Samer, M., C. Loebsin, K. von Bobrutzki, M. Fiedler, C. Ammon, W. Berg, P. Sanftleben, and R. Brunsch. 2011a. A computer program for monitoring and controlling ultrasonic anemometers for aerodynamic measurements in animal buildings. Computers and Electronics in Agriculture, Vol. 79(1): 1-12.

Samer, M., C. Loebsin, M. Fiedler, C. Ammon, W. Berg, P. Sanftleben, and R. Brunsch. 2011b. Heat balance and tracer gas technique for airflow rates measurement and gaseous emissions quantification in naturally ventilated livestock buildings. Energy and Buildings, Vol. 43(12): 3718-3728.

Samer, M. 2011a. How to construct manure storages and handling systems? IST Transactions of Biosystems and Agricultural Engineering, Vol. 1(1): 1-7.

Samer, M. 2011b. Seasonal variations of gaseous emissions from a naturally ventilated dairy barn. Misr Journal of Agricultural Engineering, Vol. 28(4): 1162-1177.

Samer, M. 2010. A software program for planning and designing biogas plants. Transactions of the ASABE, Vol. 53(4): 1277-1285.

Samer, M., H. Grimm, M. Hatem, R. Doluschitz, and T. Jungbluth. 2008a. Mathematical modeling and spark mapping for construction of aerobic treatment systems and their manure handling system. Proceedings of International Conference on Agricultural Engineering, Book of Abstracts p. 28, EurAgEng, June 23-25, Hersonissos, Crete, Greece.

Samer, M., H. Grimm, M. Hatem, R. Doluschitz, and T. Jungbluth. 2008b. Mathematical modeling and spark mapping of dairy farmstead layout in hot climates. Misr Journal of Agricultural Engineering, Vol. 25 (3): 1026 -1040. 
Schuurkes, J., and R. Mosello. 1988. The role of external ammonium inputs in freshwater acidification. Aquatic Sciences - Research Across Boundaries, 50(1): 71-86.

Shah S. B. and P. Kolar. 2012. Evaluation of additive for reducing gaseous emissions from swine waste. Agric. Eng. Int.: CIGR Journal, Vol. 14(2): 10-20.

Sommer, S.G., Christensen, B.T., Nielsen, N.E., Schjorring, J.K., 1993. Ammonia volatilization during storage of cattle and pig slurry-effect of surface cover. J. Agric. Sci. 121, 63-71.

Sommer, S.G., Pedersen, S.O., Sogaard, H.T., 2000. Greenhouse gas emissions from stored livestock slurry. J. Environ. Qual. 29, 744751.

Stevens, R.J., R.J. Laughlin, and J.P. Frost. 1989. Effect of acidification with sulphuric acid on the volatilization of ammonia from cow and pig slurries. Cambridge Journal of Agricultural Science, 113, 389-395.

Wheeler, E.F., M.A.A. Adviento-Borbe, R.C. Brandt, P.A. Topper, D.A. Topper, H.A. Elliott, R.E. Graves, A.N. Hristov, V.A. Ishler, and M.A.V. Bruns. 2011a. Amendments for mitigation of dairy manure ammonia and greenhouse gas emissions: preliminary screening. Agricultural Engineering International: CIGR Journal, 13(2): 1-14.

Wheeler, E.F., M.A.A. Adviento-Borbe, R.C. Brandt, P.A. Topper, D.A. Topper, H.A. Elliott, R.E. Graves, A.N. Hristov, V.A. Ishler, M.A.V. Bruns. 2011b. Evaluation of odor emissions from amended dairy manure: preliminary screening. Agricultural Engineering International: CIGR Journal, 13(2): 15-29.

Wheeler, E.F., P.A. Topper, R.C. Brandt, N.E. Brown, A. AdvientoBorbe, R.S. Thomas, and G.A. Varga. 2011c. Multiple-Chamber Instrumentation Development for Comparing Gas Fluxes from Biological Materials. Applied Engineering in Agriculture, 27(6): 10491060.

Williams, A., 2003. Floating covers to reduce ammonia emissions from slurry. In: Proceedings of the International Symposium on Gaseous 
and Odour Emissions from Animal Production Facilities, Horsens, Denmark, June 1-4, pp. 283-291.

\section{الملخص العربي \\ معاملة الفضلات السائله بمخلفات مصانع الاغذيه للحد من انبعاثات الميثان،

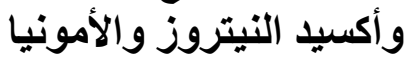

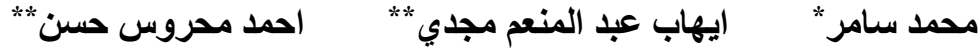

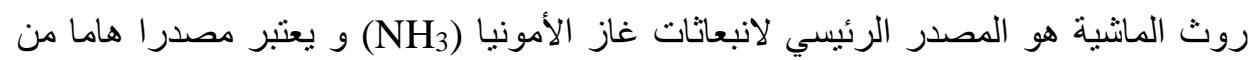

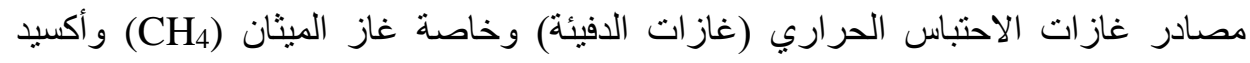

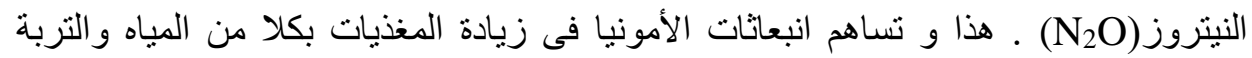

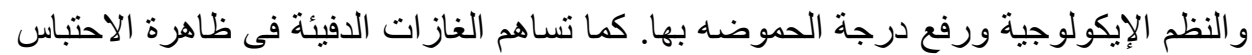

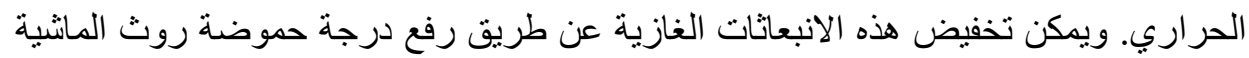

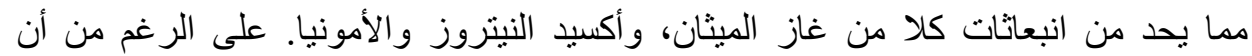

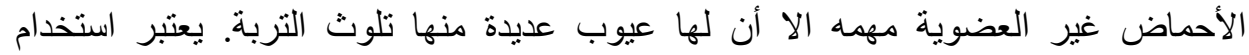

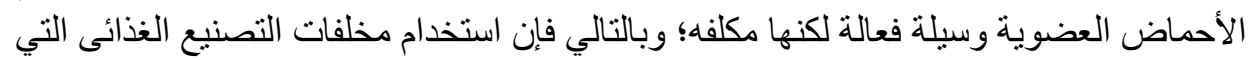

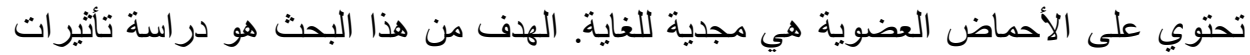

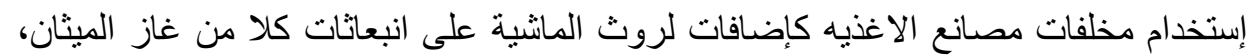

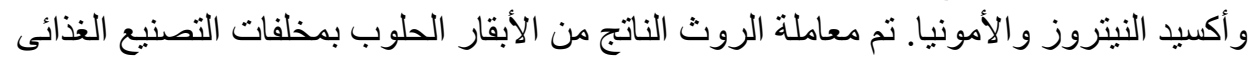

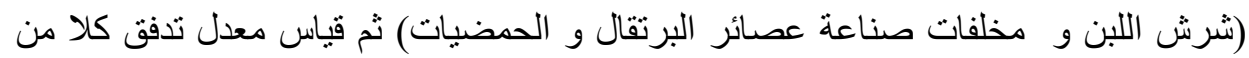

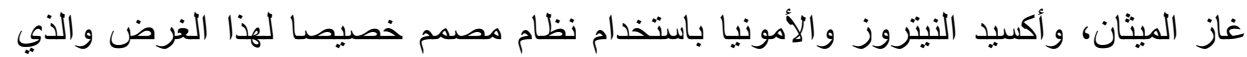

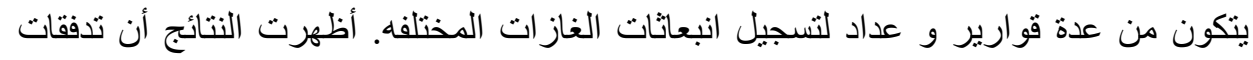

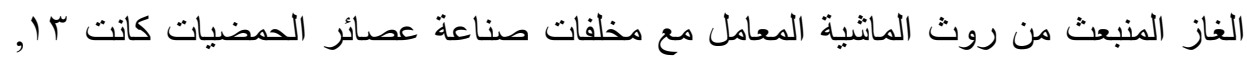

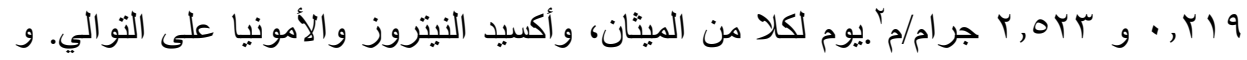

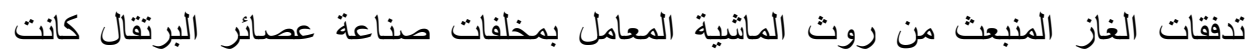

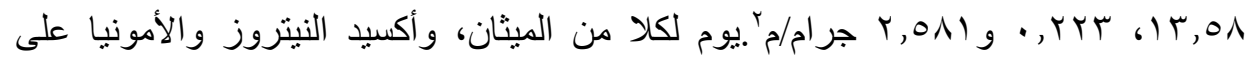

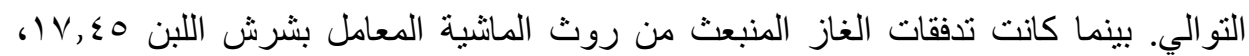

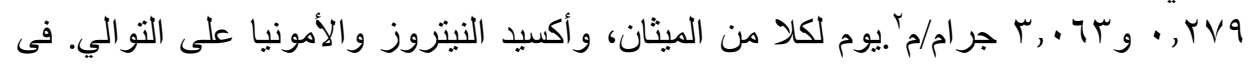

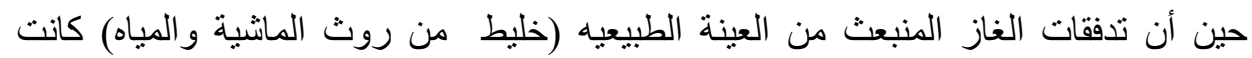

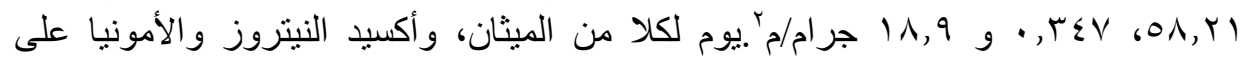

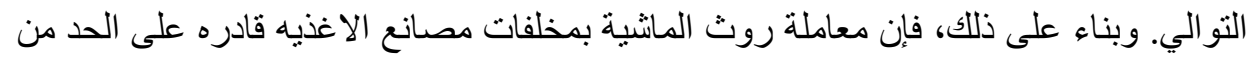
الانبعاثات الغازية من روث الماثنية.

* استاذ الهندسة الزراعية المساعد ـ كلية الزراعة ـ جامعة القاهرة. ** مدرس الهندسة الزراعية ـ كلية الزراعة ـ جامعة القاهرة. 